\title{
EchoGéo
}

$47 \mid 2019$

Nouvelles géographies de la collecte

\section{Formalization of wastepickers in Bogota and Lima: Recognize, regulate, and then integrate?}

\author{
Mélanie Rateau and Luisa Tovar
}

\section{Q OpenEdition}

Journals

Electronic version

URL: https://journals.openedition.org/echogeo/16614

DOI: $10.4000 /$ echogeo.16614

ISSN: 1963-1197

Publisher

Pôle de recherche pour l'organisation et la diffusion de l'information géographique (CNRS UMR 8586)

\section{Electronic reference}

Mélanie Rateau and Luisa Tovar, "Formalization of wastepickers in Bogota and Lima: Recognize, regulate, and then integrate? ", EchoGéo [Online], 47 | 2019, Online since 21 April 2019, connection on 11 August 2021. URL: http://journals.openedition.org/echogeo/16614 ; DOI: https://doi.org/10.4000/ echogeo.16614

This text was automatically generated on 11 August 2021.

EchoGéo est mis à disposition selon les termes de la licence Creative Commons Attribution - Pas d'Utilisation Commerciale - Pas de Modification 4.0 International (CC BY-NC-ND) 


\title{
Formalization of wastepickers in Bogota and Lima: Recognize, regulate, and then integrate?
}

\author{
Mélanie Rateau and Luisa Tovar
}

\section{Introduction}

1 Waste-picking history and its valorization are linked to the history of urbanization. The rapid urbanization process in Latin America, nourished by the migration of rural communities, whose populations are characterized by low income and underqualification (Medina, 1999), has turned informal waste-picking into a survival activity in cities with few jobs, poverty, and lack of social programs (Medina, 1999). Thus, urban waste is considered an urban deposit (Cavé, 2013), whose valuable parts represent a real resource for waste pickers, who often work in informality. They operate without being paid, funded, recognized, or formally charged for this service by the relevant authorities (Gunsilius et al., 2011; Gupta 2012).

Informality is present at all technical stages of waste management: collection, transportation, and processing by storage or recovery (Durand, 2010). Some informal actors specialize in the collection and disposal of garbage into wild dumps, while others use organic waste to feed pig farms. In this article, we are only interested in waste pickers of solid waste and non-organic waste, such as glass, paper, plastic, etc. The institutional reports (GIZ, 2011; UN-HABITAT, 2012) plead for their integration and reprove their social marginalization. This marginalization and the rejection from consumer society are linked, among other things, to their proximity to waste and vectors of disease, and their dirty appearance (Medina, 1999). This article focuses on two capital cities with more than 8 million inhabitants, Bogota in Colombia and Lima in Peru, where waste pickers benefit from a policy of social inclusion in formal waste management. 
Bogota and the fifty municipalities of Lima, responsible for waste collection and transportation services, are implementing processes to formalize waste pickers in order to convert waste picking into a selective collection service. In this regard, are the formalization processes in Bogota and Lima able to integrate waste pickers and allow them to leave marginality? Are the waste pickers integrated into this process? The initial hypothesis presented here is that the waste pickers formalization models set up on our study derive more from local institutional contexts than from a consideration of the characteristics of waste pickers' organizations. This differentiation is susceptible to produce new marginalities and exclusions.

4 This article attempts to answer these questions based on empirical data compiled during five months of internship, in 2014, five months of fieldwork in Lima, in 2015, and three months in Bogota, in 2016, as part of the ORVA2D ${ }^{1}$ research project. Also, it is founded on the GSEID ${ }^{2}$ accompaniment work to waste pickers' organizations in Bogota since 2015. The methodology is based on a literature review, interviews with municipalities, NGOs, and waste pickers, as well as visits and field observations. The first part of the article presents the environmental and social turn of waste management in favor of integrating waste pickers and then tries to demonstrate that the formalization process is much more than a mere formality. It is about recognizing, regulating, and integrating waste pickers. The second part reviews the formalization processes in Colombia and Peru. This process is done under duress in Bogota, and under subsidies in Lima. Finally, the last part focuses on the impact of informality. Early results reveal the persistence of informal recovery, even though models vary between the two terrains.

Figure 1 - Field study location

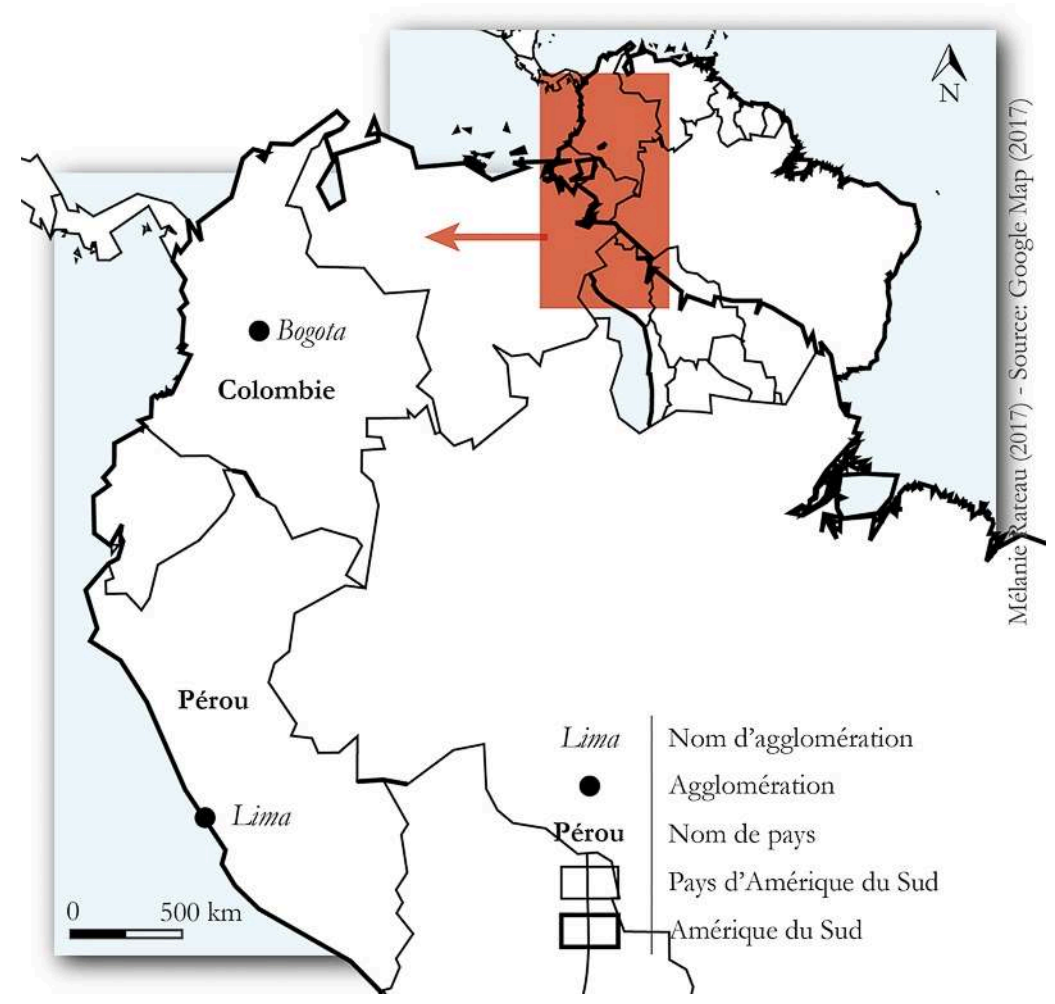

Author: M. Rateau, 2017. 


\section{Turning into the social inclusion of waste pickers}

\section{Environmental and Social Turning in Waste Management}

5 From the 1970s, waste management began a real environmental transition (Cavé, 2013), which notably led to the need for selective collection. Then, in the 2000s, the informal recovery of recyclable waste became the subject of numerous scientific and institutional works, which argued in favor of its integration into formal waste management (Cavé, 2013). This integration would participate in sustainable development by pursuing the environmental objectives of increasing recycling rates and extending landfills' lives, and economic objectives by feeding the circular economy. It would also fulfill social objectives that include providing jobs and new social recognition to a historically precarious and marginalized population (Medina, 1999; Gupta, 2012).

6 Navarrete-Hernández and Navarrete-Hernández (2018) conducted a review of the literature to identify different public policies toward informal recovery from five approaches. To begin, dualistic and voluntarist perspectives would result from repressive policies and thus from the desire to eliminate informal recovery. The structuralist approach would lead to weak support to waste pickers' organizations. The legalistic trend would lead to policies of ignorance. And the approach related to coproduction would have the potential to produce a strong policy of integration of waste pickers. Medina (2005) summarizes public policies in four forms: ignorance, repression, collusion, and integration of waste pickers. Aparcana (2017) focuses on the forms that this integration could take. It can be done through the involvement of associations and cooperatives of waste pickers, through their organization in grassroots associations or microenterprises, or finally, through the recruitment of informal waste pickers as agents of formal service.

7 The review of the literature does not reveal an ideal model allowing a formal integration of waste pickers with official waste management. Many authors agree that integration measures must be adapted to the socio-political-economic contexts of each country.

\section{Recognize, Regulate, Integrate}

8 The notion of formalization refers to the transition from informality to formality. Waste pickers' organizations must accomplish the requirements to obtain a legal status that is recognized by the authorities.

9 This process, in the case of waste picking, is more than just an administrative formality. It is accompanied by the institutional recognition of an activity and a group of people who have remained marginalized for a long time (Médina, 1999). In Colombia, the Constitutional Court, in judgment № 275 of 2011, states that "waste pickers are historically the holders of an environmental role of high importance." While in Peru, Law № 27419 specifies that “The State recognizes the activity of waste pickers, promotes their formalization and their integration into the waste management system." These texts go beyond the myth of the waste picker as a "poor victim" (Dias \& Samson, 2016). Accompanying waste pickers by considering their professional context 
is a success factor for a sustainable and positive change (Scheinberg et al., 2006). Recognition is also social. The community must be sensitized about the importance of waste segregation at the source and about the waste pickers that work to offer a selective collection service. Wearing a uniform contributes to this social recognition as well. Waste pickers no longer have an appearance similar to waste (Médina, 1999), but, rather, to professionals.

Figure 2 - Selective collection in Lima (left) and Bogota (right)

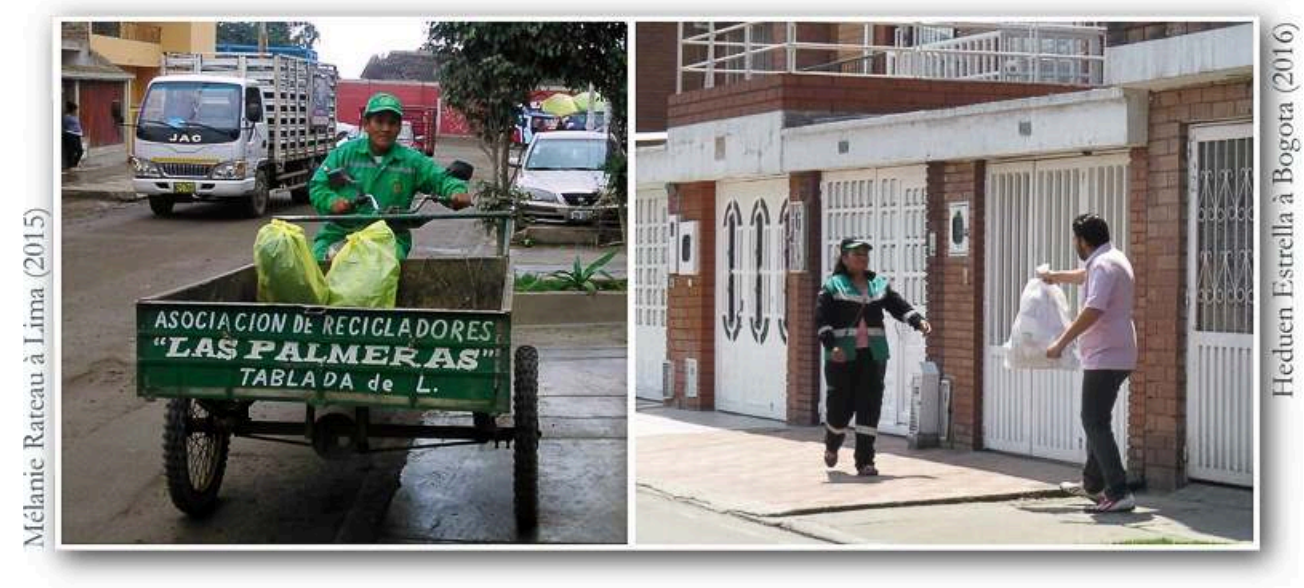

Collection achieved by formalized waste pickers wearing their uniform.

Authors : M. Rateau, Lima, 2015 (left). H. Estrella, Bogota, 2016 (right).

10 The recovery activity carried out in informality does not always respect the sectoral rules. Informal waste pickers, both in Bogota and Lima, sometimes disembowel the garbage bags in the streets to extract the recyclable waste, leaving the rest of their contents spread on the street. This example is one of many practices that harm the urban health environment. In the formalization process, governments are due to regulate waste pickers' practices and to integrate them into the waste management scheme.

\section{Formalization Process: Beyond a simple Formality}

\section{In Colombia: A Lawsuit Lead by Waste Pickers' Organizations}

The recognition of waste pickers in Colombia is the result of a judicial fight carried by their organizations. Article 25 of the 1991 Colombian Constitution states that everyone has the right to work in dignified and fair conditions. Silvio Ruiz Grisales, leader of several waste pickers' organizations, and the Association of Waste Pickers of Bogota (ARB) appealed to the Constitutional Court against the Capital District of Bogota and its Special Administrative Unit for Public Services (UAESP) on December $23^{\text {rd }}$, 2002, for violation of their fundamental right to work during the collection and transport of waste bidding, which defined criteria that was impossible to fulfill for recyclers.

The Constitutional Court imposed to the Capital District and the UAESP, through the 2003 Decision T-724, the order to guarantee the participation of waste pickers in future biddings, which the UAESP did not respect. The UAESP 2003 Resolution 114 stipulates the technical and operational regulation for the concession of waste management 
services and defines that private providers of waste collection and transport are to become responsible for selective collection. It is only since 2006 that the selective collection has become effective reaching first 74,000 households and then 700,000 households in 2008 (Parra, 2016). At the same time, only around 40 waste pickers have benefited from a social inclusion plan in a sorting space (Parra, 2016), while the vast majority remain excluded from the waste management model. Following a new legal battle, the Constitutional Court, in judgment № 275 of 2011, again canceled the bidding process. The UAESP was required to define a scheme for the formalization and regularization of the waste picker population.

In response to the Constitutional Court's judgments, and trying to overcome the transition period of the public sanitation service due to the collapse of the bidding, the District Capital had to establish a Zero Waste component at the Development Plan "Bogota Humana 2012-2016." In addition, an Integrated Waste Management Plan was formulated with a focus on recovery, aimed at promoting: (i) changes in practices for introducing source separation, (ii) reuse of waste, (iii) regularization and formalization of recycling, dignifying waste pickers' work, and the promotion of their organization into sustainable enterprises.

\section{Bogota is Forced to Integrate Waste Pickers}

The plan for integrating waste pickers was drafted to respond to the Constitutional Court's decision № 275 of 2011 and guarantee them access to recyclable waste. Then, on February $20^{\text {th }}$ and August $9^{\text {th }}, 2013$, resolutions № 119 and № 388 set down the remuneration procedure for waste pickers in Bogota. Following the adoption of these district policies, the public waste management company recovered the provision of selective collection routes operated by private providers, before distributing these routes among the waste pickers' organizations that had the legal status warrant. This legal status is obtained following the individual registration of each recycler and his or her association in the public register of the UAESP, the signing of a co-responsibility agreement, and registration in the Public Services Superintendence.

In 2015, this local policy becomes national with the approval of the decree № 1077 , which recognizes the collection of recyclable materials as a complementary activity of waste management public service. This decree is followed in 2016 by decree № 596, which approves the transitional regime for waste pickers' formalization. They have a period of five years to accomplish the technical, administrative, commercial, and financial requirements to participate in the biddings process. Waste pickers' organizations must take on accounting management, route control with georeferencing systems, handling of complaints and claims, among other requirements in order to be at the level of a public service private company.

From this formalization process, the remuneration for the service provided represents one of the most significant advances for the recognition of waste pickers' work (Parra, 2015). Recyclers confirm ${ }^{3}$ that they are paid according to the number of recyclable materials collected, in addition to their transportation to authorized weighing centers. The remuneration amount is fixed according to the costs avoided by the nonmanagement of recyclable waste by the collection-disposal service. Then, the waste pickers get a second income from the sale of recyclable materials. However, access to this urban resource for waste pickers seems to be compromised. They fear future 
competition with private companies: "Already three years out of five years of formalization. And in two years, they will destroy us all." ${ }^{4}$

\section{In Peru: Legislation Helped by the Mobilization of an NGO}

17 Since the 1990s, waste recycling in Peru has been governed by legislation that is dense but too strict towards waste recovery activity (Durand, 2010). According to the General Waste Law of 2000, only companies registered under the status of Solid Waste Company Provider Services or Solid Waste Company Marketing have the right to sort, sell, and commercialize waste for recycling. The large conditions to fulfill in order to obtain these statutes are inaccessible to waste pickers, thus preventing them from exercising their activity in compliance with the legislation. As a result, the municipalities carried out repressive measures against them, in particular by confiscating their tricycles and carts.

In this context, the NGO Ciudad Saludable was born in 2002 with the objective of promoting the recognition of waste pickers' activity. To reach this goal, they supported the creation of the National Federation of Recyclers of Peru (FENAREP) in 2005 through which discussions with the Ministry of the Environment began (Samson, 2009). After some disagreements between FENAREP and the NGO, especially about the zoning of selective collection ${ }^{5}$, a new waste pickers' organization, called the National Movement of Waste Pickers of Peru (MNRP), was created in 2008. That same year, a commission composed by the Ministry of the Environment, the NGO Ciudad Saludable, the MNRP, and civil society representatives, was responsible for a law project draft (Samson, 2009) aimed at supervising the practice of recovering waste.

Law № 29419, known as the Recycler's Law, was adopted on October $7^{\text {th }}, 2009$. It aims to encourage waste pickers' formalization and the implementation of selective collection through their integration into municipal management.

\section{Ministerial Subsidies to Encourage Municipalities of Lima}

The new legislation regulating waste pickers' activity designates the district municipalities as responsible for the formalization of these actors and the implementation of the sorting program and selective collection of recyclable materials (PSF-RS). To encourage recyclers to commit to this process, the government has launched a subsidy campaign rewarding the achievement of annual targets. For example, in July 2014, if $25 \%$ of urban households in the district were registered for the PSF-RS, the municipality would receive a ministerial subsidy (República del Perú 2014).

The formalization and the PSF-RS are adaptable to each municipality as defined and adopted by municipal ordinances. Only the major stages of the administrative process are framed by the law. This process begins with a campaign to identify waste pickers. They are registered and receive a document necessary to access a compulsory training, a vaccination campaign, and free affiliation to health insurance. The formalization is materialized during their registration in the municipal register by mentioning which association they depend on. The waste pickers cannot be formalized as independent recyclers. They must organize themselves in an association to carry out selective collection within the PSF-RS. 
Municipalities must simultaneously implement their PSF-RS to assign collection areas to formal waste pickers. They map out these areas, ensure the sensitization of households to selective sorting, and note the contact details of those wishing to participate in the program. Then, each recycler ensures selective collection in the area assigned by the municipality. This collection is done door-to-door, receiving sorting bags from the households registered in the PSF-RS. The new regularity of income and social acceptance are the main attractions of waste pickers' formalization. As a recycler explains: "I formalized because the municipality offered us an opportunity for the neighbors to recognize us as the people we are: workers, and so we do not have that fear that any day they make a raid and confiscate the tricycle, all that." ${ }^{6}$

\section{Models with Contrasting Impacts on the Informality}

\section{Informality Persistence}

The outcomes of the formalization process in Bogota and Lima reveal the persistence of informal recovery. Take the example of Lima. The impact of the new regulations is minimal, both in terms of the number of integrated waste pickers and the tonnage of selective collection. In Comas, there are 40 waste pickers who are formalized or in the formalization process, that represents only $2 \%$ of waste pickers according to the estimates of the NGO Ciudad Saludable (Ruiz Ríos, 2010). These waste pickers collect nearly 300 tons of recyclable material per year, less than $1 \%$ of the district's recyclable waste. Informal pickers are more numerous than formal ones, and the total tonnages that they capture are probably more important.

Figure 3 - Informal Recyclers in Lima (left) and Bogota (right)

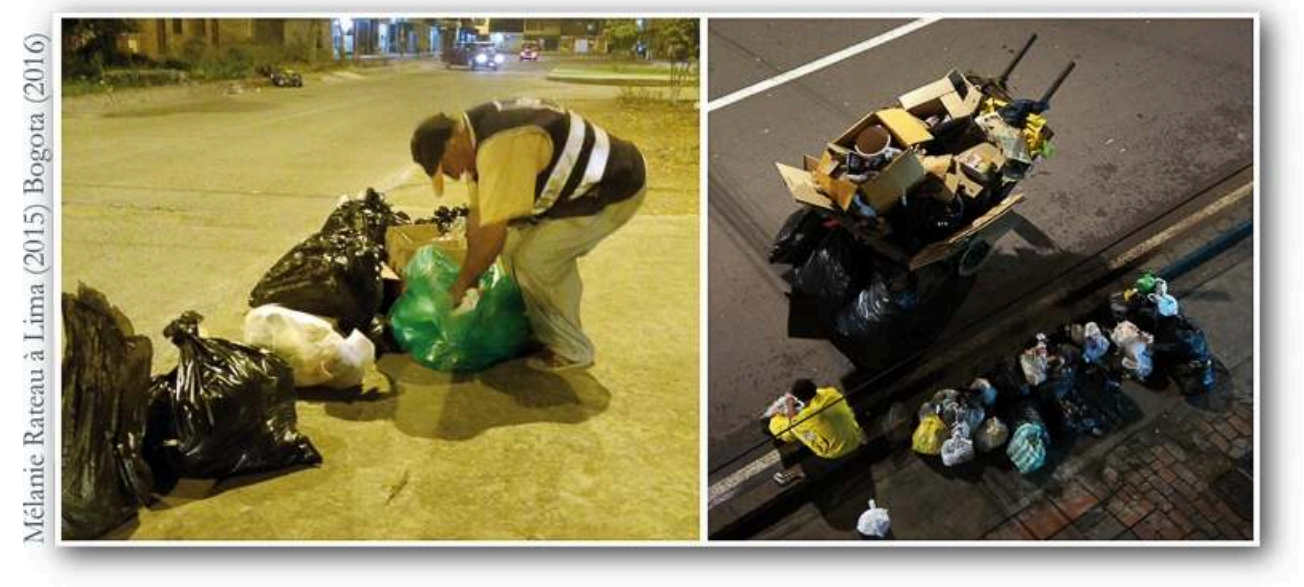

These informal recyclers are opening bags in search of recyclable materials. Authors : M. Rateau, Lima, 2015 (left). M. Rateau, Bogota, 2016 (right).

Faced with this competition, the formal waste pickers are asking the municipality to hunt informal waste pickers ${ }^{7}$. The new formality offers advantages that are not enough to motivate waste pickers to invest in the long process of formalization. The generalization of the selective collection can be considered as an alternative to repressive policies. Its extension to all households should limit informal recovery by reducing the amount of recyclable waste available in garbage bags on the road. 
25 As for Bogota, the new formality attracts waste pickers. As of April 2018, there were 100 organizations of waste pickers duly formalized (SSPD, 2018) to benefit from municipal remuneration, considering the 176 identified in 2012 (UAESP, 2012). These results may be due to the attractive remuneration and the process resulting from the mobilization of waste pickers.

\section{Upgrade Waste Pickers or Simplify Regulations}

The literature review highlights different typologies of public policy towards informal recovery. The models of Bogota and Lima are two distinct models of integration that do not fit perfectly in the boxes proposed by Navarrete-Hernández and NavarreteHernández (2018). This holds in particular pre-existing contexts to the policy of formalization and integration. In Bogota, selective recovery was operated by private providers before the new regulations imposed a transitional regime for integrating waste pickers. In Lima, the majority of districts did not practice selective recovery, but only garbage collection. In Bogota, waste pickers have five years to upgrade to private providers in order to enter into a competitive scheme. In Lima, the regulation has been simplified to be within reach for recyclers.

Requiring an upgrade from waste pickers might lead to perverse effects. Large organizations are consolidated while smaller ones fear becoming empty shells when their members join the larger ones ${ }^{8}$. The long-term risk is that many organizations might not be able to keep up with this forced development and could fall back into informality. The choice to simplify regulation, as operated in Lima, offers the advantage of retaining flexibility and autonomous characteristics that are specific to informality, which waste pickers do not wish to abandon (ESCAP, 2015). However, the lack of technical, financial and organizational assistance may limit the economic development of waste pickers' organizations by confining them to picking activity. This assistance role is sometimes led by NGOs when municipalities engage them to accompany the formalization process. For example, the NGO Alternativa had a project called Recicla para la vida (2012-2015), which offered micro-credits and support for the creation of pre-treatment and marketing waste companies to waste pickers' organizations wishing to develop their activities.

\section{Conclusion}

The integration policies of waste pickers in Bogota and Lima come up from local sociopolitical-economic contexts. In Bogota, selective collection pre-existed the judicial battle of waste pickers' organizations. Their integration is done by upgrading them to private providers during a transitional five-year period, with the aim to compete in future bidding processes for selective collection services. In Lima, few municipalities implemented selective sorting measures before the Recycler Law. Waste picker inclusion is an opportunity for the supply of this new service. The regulations have been simplified to facilitate their formalization.

The implementation of formalization processes makes it possible to recognize waste picking activity and their workers, to regulate practices, and to integrate recyclers into formal waste management. Putting an end to the informality of this sector is not within the scope of these processes which concern only recyclers of solid waste. Instead, they 
are helping to end the marginalization of the practice of recovering this waste. In Bogota, this practice was already institutionalized, but in Lima, the municipalities actively sensitize the population. The selective collection is done by recovering the sorting bags from the hands of households. Searching the garbage bags accessible on the road should be reduced and marginalized.

The recognition of waste pickers as professionals in the waste management sector would be a factor in the success of a sustainable and positive change (Schneinberg et al., 2006). However, this recognition is only the first step of a transitional regime in Bogota. Waste pickers' organizations must enter into a logic of forced development to convert them into organizations that respect the same requirements as those demanded from private or public service providers. Waste pickers are advancing in the process of formalization, fearing to fall back into informality during the last theoretical stage of the competition. In Lima, the simplification of regulations and the lack of support for waste pickers risk locking them into recovery activities, without offering them the opportunity to develop other activities that improve their life conditions. The law regulating their activity is largely due to the mobilization of an NGO. This may explain an NGO-dependent formalization model for assistance to organizations.

Integration policies and formalization processes in Bogota and Lima are at their outset. Currently in Bogota, organizations are only in the early stages of the process. In Lima, the new formality is struggling to attract waste pickers, and the commitment of municipalities in these processes depends on governmental subsidies. It is necessary to follow the evolution of these policies and processes over time to know the consequences of waste pickers' marginalization or inclusion.

\section{BIBLIOGRAPHY}

Aparcana S., 2017. Approaches to formalization of the informal waste sector into municipal solid waste management systems in low- and middle-income countries: Review of barriers and success factors. Waste Management, 1 mars 2017, vol. 61, p. 593-607.

Cavé J., 2013. La gestion disputée d'un mal public impur : économie politique des ordures. Thèse de doctorat en architecture, aménagement de l'espace, Université Paris-Est, Champs-sur-Marne, $459 \mathrm{p}$.

Dias S. M. et Samson M., 2016. Informal economy monitoring study sector report : waste pickers. WIEGO, Cities inclusive, IEMS, $60 \mathrm{p}$.

Durand M., 2010. Gestion des déchets et inégalités environnementales et écologiques à Lima : entre durabilité et vulnérabilité. Thèse de doctorat de Géographie et Aménagement de l'espace, Université de Rennes 2, 486 p.

Escap, 2015. Valuing waste, transforming cities, Economic and social commission for Asia and the Pacific. United Nations publication, $129 \mathrm{p}$.

GIZ, 2011. Recovering resources, creating opportunities: integrating the informal sector into solid waste management. Deutsche Gesellschaft für Internationale Zusammenarbeit, $54 \mathrm{p}$. 
Gunsilius E., Chaturvedi B., Scheinberg A., Coad A. et Garcia Cortes S., 2011. The economics of the informal sector in solid waste management. Eschborn, CWG, GIZ, 36 p.

Gupta S. K., 2012. Intégrer le secteur informel pour une meilleure gestion des déchets. Secteur Privé \& Développement, $\mathrm{n}^{\circ}$ 5, p. 12-17.

Médina M., 1999. Reciclaje de desechos solidos en America Latina. Frontera norte, vol. 11, $\mathrm{n}^{\circ} 21$, p. 7-31.

Medina M., 2005. Serving the unserved: informal refuse collection in Mexico. Waste Management \& Research, vol. 23, $\mathrm{n}^{\circ}$ 5, p. 390-397.

Navarrete-Hernandez P., Navarrete-Hernandez N., 2018. Unleashing waste-pickers' potential : supporting recycling cooperatives in Santiago de Chile. World Development, vol. 101, p. 293-310.

Parra F., 2015. Reciclaje: jsí, pero con recicladores! Gestión pública del aprovechamiento con inclusión de recicladores: un nuevo paradigma en el manejo de los residuos en Bogotá. Nota Técnica de WIEGO 9 (Políticas Urbanas).

Parra F., 2016. De la dominación a la inclusion : la población recicladora organizada como sujeto politico. Tesis de doctorado en estudios politicos y relaciones internacionales, Universidad Nacional de Colombia, Bogota, $624 \mathrm{p}$.

Republica del Peru, 2014. Decreto Supremo No033-2015-EF. Aprueban los procedimientos para el cumplimiento de metas y la asignación de los recursos del plan de incentivos a la mejora de la gestión y modernización municipal del año 2015.

Ruiz Ríos A., 2010. Por la ruta del reciclaje en el Perú. Estudio socioeconómico de la cadena de reciclaje. Lima, Ciudad Saludable.

Samson M., 2009. Rechazando a ser excluidos : la organizacion de los recicladores en el mundo. WIEGO, Cambridge, $116 \mathrm{p}$.

Scheinberg, A., Anschütz, J., Van de Klundert A., 2006. Waste pickers: poor victims or waste management professionals?. Paper $n^{\circ} 56$, CWG-WASH Workshop (Kolkata, India, 1-5 February 2006).

Sspd, 2018. Système Unique d'information [En ligne]. http://www.sui.gov.co (page consultée en octobre 2018)

Uaesp, 2012. Plan de Inclusión de la Población y Organizaciones de Recicladores en la Gestión Pública de Residuos Sólidos Reciclables en Bogotá D.C. Bogotá D.C., Secretaria de Hábitat, Ed.

UN-HABITAT, 2012. Recycling and disposal of municipal solid waste in low and middle-income countries: Perspectives for municipal managers and environment agencies. Nairobi, UN-HABITAT, 224 p.

\section{NOTES}

1. The research project ORVA2D (OrRganization of Waste Administration in Developing Countries) was led by the ESO laboratory (UMR 6590) of the University of Le Mans with AFD funding.

2. GSEID, Socioeconomics, Institutions and Development Research Group of the National University of Colombia.

3. Group interview with waste pickers of a Kennedy organization in Bogota, directed by Mélanie Rateau and Heduen Estrella, on 01/29/2016.

4. Formalized recycler speech during a public hearing, collected by Luisa Tovar on 07/27/2018. 
5. Interview with Juan Herrera, president of FENAREP in Lima, directed by Mélanie Rateau on $04 / 16 / 2014$.

6. Interview with a recycler from the municipality of San Martin de Porres, in northern Lima, directed by Mélanie Rateau on 03/19/2014.

7. Interview with a recycler from the municipality of San Martin de Porres, in the north of Lima, directed by Mélanie Rateau on 05/25/2014.

8. Interview with collectors of Bogota directed by Heduen Estrella, the 03/10/2016.

\section{ABSTRACTS}

Waste management models in Colombia and Peru are at a turning point in favor of the integration of informal waste pickers. The Capital District of Bogota and Lima's fifty municipalities are putting in place formalization processes that are more than just a formality. It involves recognizing, regulating and integrating wastepickers. The study of the processes at work in these two cities reveals distinct models of formalization with contrasting impacts on the informality and the marginality of a practice and the population dedicated to it.

Les modèles de gestion des déchets en Colombie et au Pérou connaissent un tournant en faveur de l'intégration des récupérateurs informels des déchets. Le District Capital de Bogota et les cinquante municipalités de Lima mettent en place des processus de formalisation qui sont bien plus qu'une simple formalité. Il s'agit de reconnaitre, de réguler et d'intégrer les récupérateurs de déchets. L'étude des processus à l'œuvre dans ces deux villes révèle des modèles de formalisation distincts aux impacts contrastés sur l'informalité et la marginalité d'une pratique et de la population qui s'y dédie.

\section{INDEX}

Mots-clés: formalisation, récupérateur informel, gestion des déchets, Bogota, Lima

Keywords: formalization, informal wastepicker, waste management, Bogota, Lima

Subjects: Sur le Champ - Sur le Terrain

\section{AUTHORS}

\section{MÉLANIE RATEAU}

Mélanie Rateau, melanie.rateau@hotmail.com, is a Ph.D. student in geography at Latts (UMR 8134), ENPC.

\section{LUISA TOVAR}

Luisa Tovar, lftovarc@unal.edu.co, is a Ph.D. student in Economics at the National University of Colombia. 